\title{
Influence of Age of Apple Flowers on Growth of Erwinia amylovora and Biological Control Agents
}

\author{
S. V. Thomson and S. C. Gouk, Department of Biology, Utah State University, Logan 84322-5303, and Ruakura \\ Research Centre, HortResearch, Hamilton, New Zealand
}

\begin{abstract}
Thomson, S. V., and Gouk, S. C. 2003. Influence of age of apple flowers on growth of Erwinia amylovora and biological control agents. Plant Dis. 87:502-509.
\end{abstract}

The influence of flower age on growth of Erwinia amylovora, the causal pathogen of fire blight of apples and pears, was investigated under humid and arid conditions in Hamilton, New Zealand (NZ), and Logan, UT, USA, respectively. 'Royal Gala' apple flowers ranging from 1 to 8 days old were atomized with E. amylovora. Pistils were dissected and washed separately from the remaining floral parts (flowers ex pistils) for estimation of bacterial numbers. Pistils, 1 to 3 days old (USA) and 1 to 4 days old (NZ), supported exponential growth of E. amylovora, but bacterial populations did not increase when older flowers were inoculated. Scanning electron microscopy showed round and turgid papillae on stigmas of 1-day-old flowers. Papillae on 4- to 6-day-old stigmas were completely collapsed and covered in mucilage. Populations of E. amylovora on the flowers ex pistils were characteristically lower than pistil populations. High populations of saprophytic bacteria were found on both floral parts of all ages, but there was no difference in their numbers on 3- to 6-day-old pistils. This suggests their presence did not inhibit the growth of E. amylovora on older stigmas. The results demonstrate that stigmas on 1- to 3-day-old flowers often support rapid growth of E. amylovora, but flowers inoculated when more than 4 to 5 days old do not support growth or only limited growth. The same location and pattern of bacterial growth occurred with the biological control agents Pseudomonas fluorescens PfA506nr and Pantoea agglomerans (Erwinia herbicola) Eh318nr. The distinct effect of flower age on growth of antagonistic bacteria and E. amylovora may be important in deciding when to treat with biological control organisms or bactericides.

Additional keywords: etiology, flower physiology

The pathogen Erwinia amylovora causes infection of the flowers, shoot tips, and branches of apple and pear trees (20). Flower infection often occurs when the bacterium multiplies to high numbers, primarily on the stigmas of apple and pear flowers. Rain or free moisture spreads the bacteria to the hypanthium, where infection occurs, resulting in blossom blight $(16,17)$. Despite high populations of the pathogen on the stigmas, they are not the most common sites of infection $(12,16)$. The hypanthium is the most common primary infection point in apple and pear flowers. The epiphytic growth of E. amylovora on the stigmas and the near simultaneous transfer of high populations of bacteria into the hypanthium clarify how concurrent infections of many flowers in an orchard occur following a rainstorm.

Corresponding author: S. V. Thomson

E-mail: shermt@ext.usu.edu

Current address of S. C. Gouk, Department of Natural Resources and Environment, Private Bag 1, Tatura, Victoria 3616, Australia.

Accepted for publication 8 December 2002.

Publication no. D-2003-0317-01R

(C) 2003 The American Phytopathological Society
Preliminary observations in experiments conducted in the 1995 season suggested that E. amylovora was unable to multiply on the stigmas of older apple flowers (2). The phenomenon of stigma aging in relation to establishment of E. amylovora was interesting in view of the close relationships linking colonization on stigmas and dispersal to the infection sites in the hypanthium (16). Most studies of the maturation of flowers have been focused on pollination rather than any effect on susceptibility to pathogens $(5,6,8)$. Studies of the development of the stigmatic surface of Malus spp. or other plants in the Rosaceae family have dealt with the normal interactions of stigmatic surface and pollen grains (14).

Detailed investigations were carried out to compare two geographical locations and the corresponding environmental conditions on the effect of flower age and the growth of $E$. amylovora on the stigma. It was thought useful to compare the behavior of E. amylovora in Hamilton, New Zealand, where conditions are normally humid with Utah, USA, where conditions are much more arid. Preliminary results of this research have been reported previously $(2,4)$.

\section{MATERIALS AND METHODS}

Bacterial population studies in New Zealand. Experiments were conducted in
October 1996 at the Blands Research Orchard, Hamilton. Apple flowers on 3-yearold trees of cv. Royal Gala were marked each day as they opened by painting a small dot on the individual pedicels for 8 days. Up to 60 newly opened flowers on each tree were painted. Each flower age treatment was replicated on five trees in a randomized block design with only one age of flowers per tree. On the eighth day, flowers of all ages, 1 to 8 days, were inoculated simultaneously with E. amylovora strain Ea8865nr, selected for resistance to the antibiotics nalidixic acid and rifampicin. Marked flowers were atomized with the inoculum at an approximate concentration of $3 \times 10^{7} \mathrm{CFU} / \mathrm{ml}$. After the flowers were dry, three flowers were sampled daily from each of the five replicate trees for 8 days (15 total) after inoculation. Each day we processed 120 flowers total $(8 \times 15)$. Over the 8-day period, we processed 960 flowers. The pistils were removed and washed separately from the rest of the flower parts without pistils (flower ex pistils) in 5 and $10 \mathrm{ml}$ of phosphate buffered saline, respectively. An aliquot of 0.1 $\mathrm{ml}$ of the wash was spread on King's medium B (7) amended with rifampicin and nalidixic acid at $100 \mu \mathrm{g} / \mathrm{ml}$ for estimation of the inoculated bacterial population on each flower part.

The growth of the biocontrol bacteria, Pseudomonas fluorescens PfA506nr and Pantoea agglomerans (E. herbicola) Eh318nr, on 1- to 8-day-old flowers on 3year-old trees of cv. Royal Gala was studied at the Blands Research Orchard in October 1996. The trees used for each saprophytic bacterium were separated from each other and from the trees used for $E$. amylovora by at least $15 \mathrm{~m}$ to prevent spread. Both antagonistic bacteria were selected for resistance to nalidixic acid and rifampicin to aid in selection and identification on media amended with the antibiotics. Flowers were marked, inoculated, and processed with the same protocol used for E. amylovora. The experimental design was a complete randomized block with five single-tree replications for each day. Isolations from each flower were conducted as noted for E. amylovora above with 15 flowers sampled per age and 120 total for each day $(8 \times 15)$. Over the 8 -day period, we processed a total of 960 flowers $(8 \times 120)$.

An experiment on naturally occurring bacterial populations on flowers of various 
ages was conducted to determine whether the inability of E. amylovora to grow on older stigmas was due to the presence of higher saprophytic bacterial populations on these tissues. Apple cv. Royal Gala flowers, 1 to 5 days old, at the Blands Research Orchard NZ were processed during November 1998 for estimation of natural bacterial populations as described in the above experiments. Three flowers were sampled from each of three trees per age treatment $(3 \times 3 \times 5)$ and processed as noted above. The flower wash was plated on King's medium B without any antibiotic incorporated.

Bacterial population studies in the United States. The population dynamics of E. amylovora were studied at the Utah State University, Kaysville Research Orchard, UT, during April and May 1997. The experiment was similar to that conducted in New Zealand with slight modifications. The petioles of about 100 freshly opened cv. Royal Gala apple flowers per tree on 7-year-old trees were marked with paint. New flowers were marked on six consecutive days and replicated on five trees in a randomized block design. On the sixth day, flowers of all ages were inoculated simultaneously with Ea8865nr. Flowers were sprayed to runoff with an inoculum concentration of $5 \times 10^{8} \mathrm{CFU} / \mathrm{ml}$. Three flowers per five replicate trees representing flower ages from 1 to 6 days were sampled each day over 8 days. $(3 \times 5$ $\times 6 \times 8)$. Populations of $E$. amylovora were quantified as described for the NZ experiment.

The incidence of fire blight on the remaining flowers not sampled for population estimation was assessed 2 to 3 weeks after inoculation in both the NZ and USA studies. The proportion of individually marked flowers that were infected was assessed in the NZ study, whereas the proportion of infected flower clusters was assessed in the USA study. There were about 500 flowers per treatment in NZ and 100 flower clusters per treatment in the USA study available for fire blight incidence.

Scanning electron microscopy (SEM) examination. Changes in stigma morphology over time that might affect establishment of E. amylovora were investigated in a separate experiment in November 1998 at the Blands Research Orchard. Samples of apple flowers, 1 to 5 and 7 days old, of cv. Royal Gala were either not inoculated or inoculated with Ea8865nr at approximately $10^{6} \mathrm{CFU} / \mathrm{ml}$. After flowers were dry, pistils were extracted and the hypanthium was dissected by removing the stamens and petals. The pistil and hypanthium samples were immediately immersed in $2 \%$ glutaraldehyde in $0.06 \mathrm{M}$ sodium-cacolydate buffer for fixation. Similar samples from flowers 1 to 6 days old from the field study in Kaysville, UT, were processed using the same method. Flower parts were washed in buffer and then dehydrated in an ethanol series $(10,30,50,70,95$, and 100\% 3 times) and critical-point-dried in an Emscope CPD 750 critical point drying unit using carbon dioxide as the transitional fluid. Dried material was coated with gold using a Polaron 5100 sputter coating unit and viewed in a Philips PSEM 505 scanning electron microscope at an accelerating voltage of between 12 and $15 \mathrm{kV}$.

Weather data. The weather data during September and October 1996 at Blands Research Orchard and that for April and May 1997 at the Kaysville Research Orchard were obtained from automatic weather stations (9). Maximum and minimum daily temperatures, and rainfall, were entered in the MARYBLYT fire blight predictive model (15) to assist with evaluation of conditions suitable for fire blight infection.

Statistical analysis. The colony count obtained per floral part was used to derive a mean colony count per sample on each day. The colony counts were transformed using $\log _{10}$ (sample count +1 ) prior to statistical analysis. Data for each day after inoculation were examined separately using one-way analyses of variance to assess the effect of age of flowers on the growth of bacteria on pistils and flowers ex pistils. Means among flower ages were compared

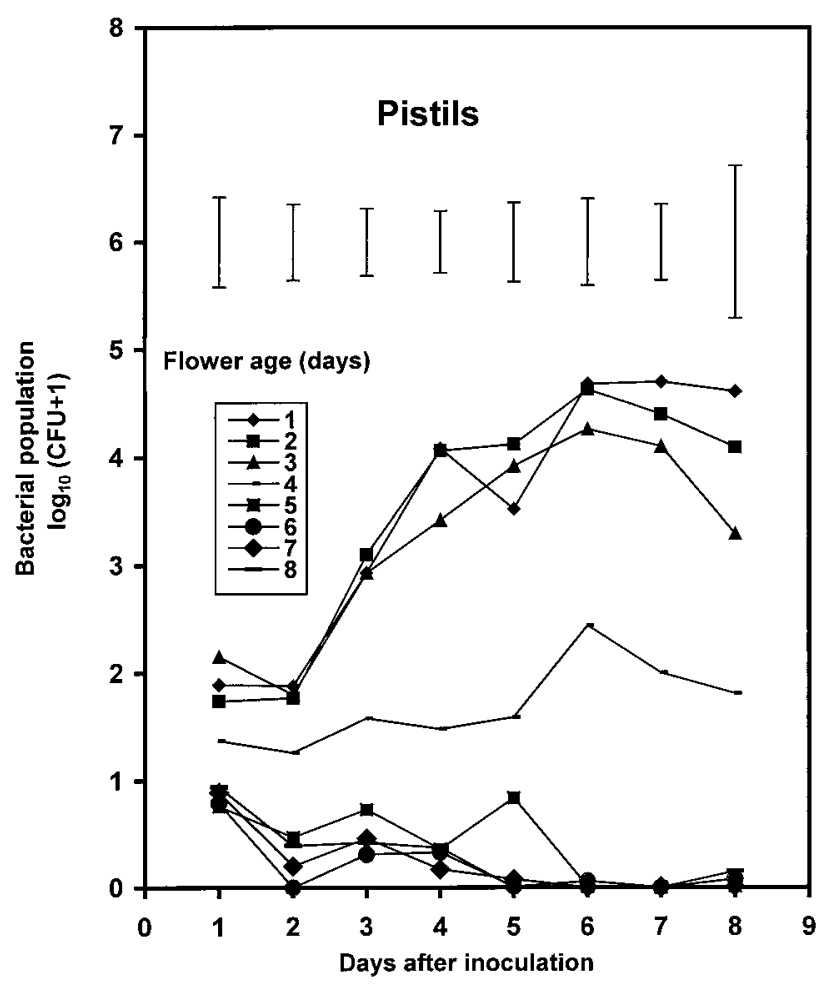

Fig. 1. Population dynamics of Erwinia amylovora on pistils of cv. Royal Gala flowers inoculated when 1 to 8 days old at Blands Research Orchard, Hamilton, New Zealand. E. amylovora was applied at a concentration of $3 \times 10^{7} \mathrm{CFU} / \mathrm{ml}$. Each point is the mean of counts from excised pistils from 15 flowers. Bars at top are LSD (0.05) values for each day after inoculation.

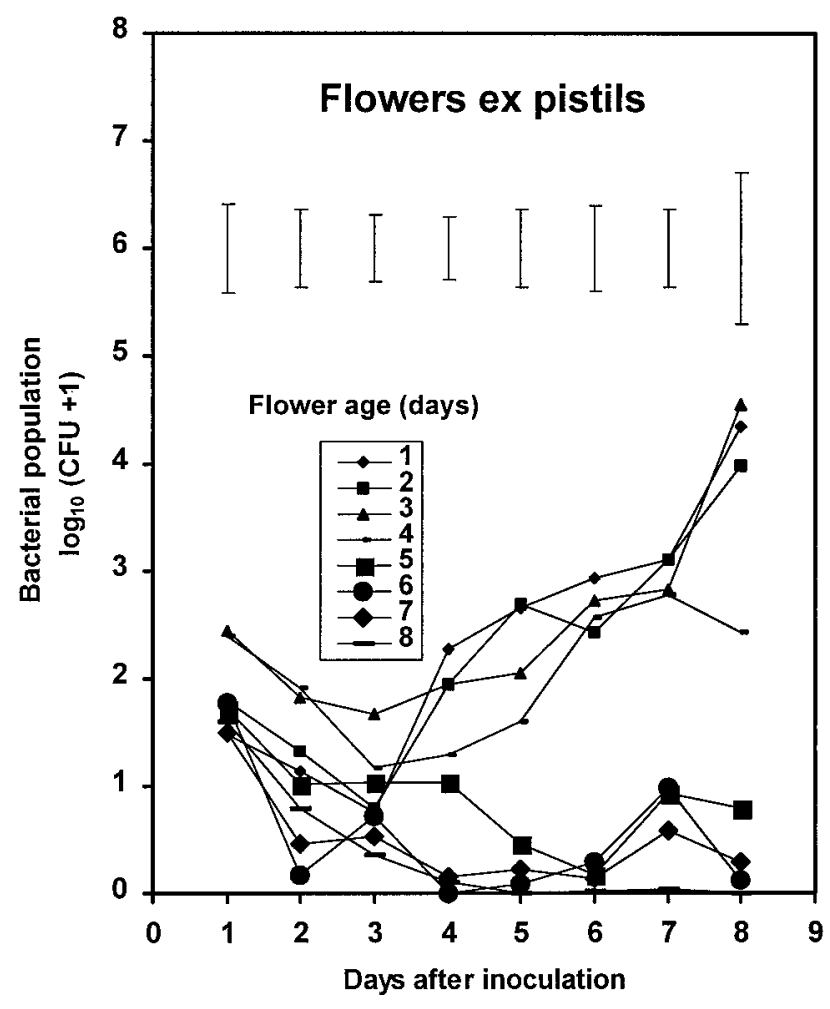

Fig. 2. Population dynamics of Erwinia amylovora on apple flowers ex pistils of cv. Royal Gala inoculated when 1 to 8 days old at Blands Research Orchard, Hamilton, New Zealand. E. amylovora was applied at a concentration of $3 \times 10^{7} \mathrm{CFU} / \mathrm{ml}$. Each point is the mean of counts from 15 flowers ex pistils. Bars at top are LSD (0.05) values for each day after inoculation. 
pairwise using Fisher's least significant difference (LSD).

A one-way analysis of variance was used to determine whether the incidence of fire blight, measured as a percentage of infected flowers or flower clusters, differed with the age of flowers at the time of inoculation with E. amylovora. Means were compared pairwise using Fisher's LSD. Data were analyzed with GenStat 5 (NAG Ltd., Oxford, England).

\section{RESULTS}

Studies in New Zealand. E. amylovora was recovered from pistils of all ages on the day of inoculation (sampling day 1) (Fig. 1). Subsequently, E. amylovora populations significantly increased $(P=0.01)$ on pistils inoculated when 1 to 3 days old, but populations on pistils inoculated when flowers were older than 4 days old remained close to the level found on the day of inoculation. No E. amylovora or very low numbers were recovered from pistils that were inoculated when older than 4 days (Fig. 1).

The bacterial populations did not increase immediately after inoculation but required a lag time of 1 to 2 days for multiplication. Subsequently, on pistils from flowers 1 to 3 days old, bacterial populations multiplied from approximately $10^{2}$ CFU per sample on the day of inoculation to $10^{4.5} \mathrm{CFU}$ per sample 6 days after inoculation (Fig. 1). The populations on flowers ex pistils of the same age decreased for 3 days (Fig. 2). The populations on pistils reached the highest levels 6 days after inoculation (Fig. 1). Bacterial populations on the flowers ex pistils that were inoculated when 5 to 8 days old remained at low levels throughout the course of the study (Fig. 2). The rise in populations on the flowers ex pistils on day 8 coincided with rain that occurred on that day, 22 October (Table 1). No rain was recorded in the previous 7 days after inoculation.
As in the studies with E. amylovora, significantly higher $(P=0.01)$ numbers of PfA506nr (Fig. 3) and Eh318nr (Fig. 4) were obtained from 1- to 4-day-old pistils. Pistils on flowers older than 4 days did not support high numbers of antagonistic bac- teria. The numbers of both PfA506nr and Eh318nr were low on flowers ex pistils, similar to the growth of E. amylovora on flowers ex pistils (Fig. 2).

The naturally occurring saprophytic bacterial populations on flowers of various

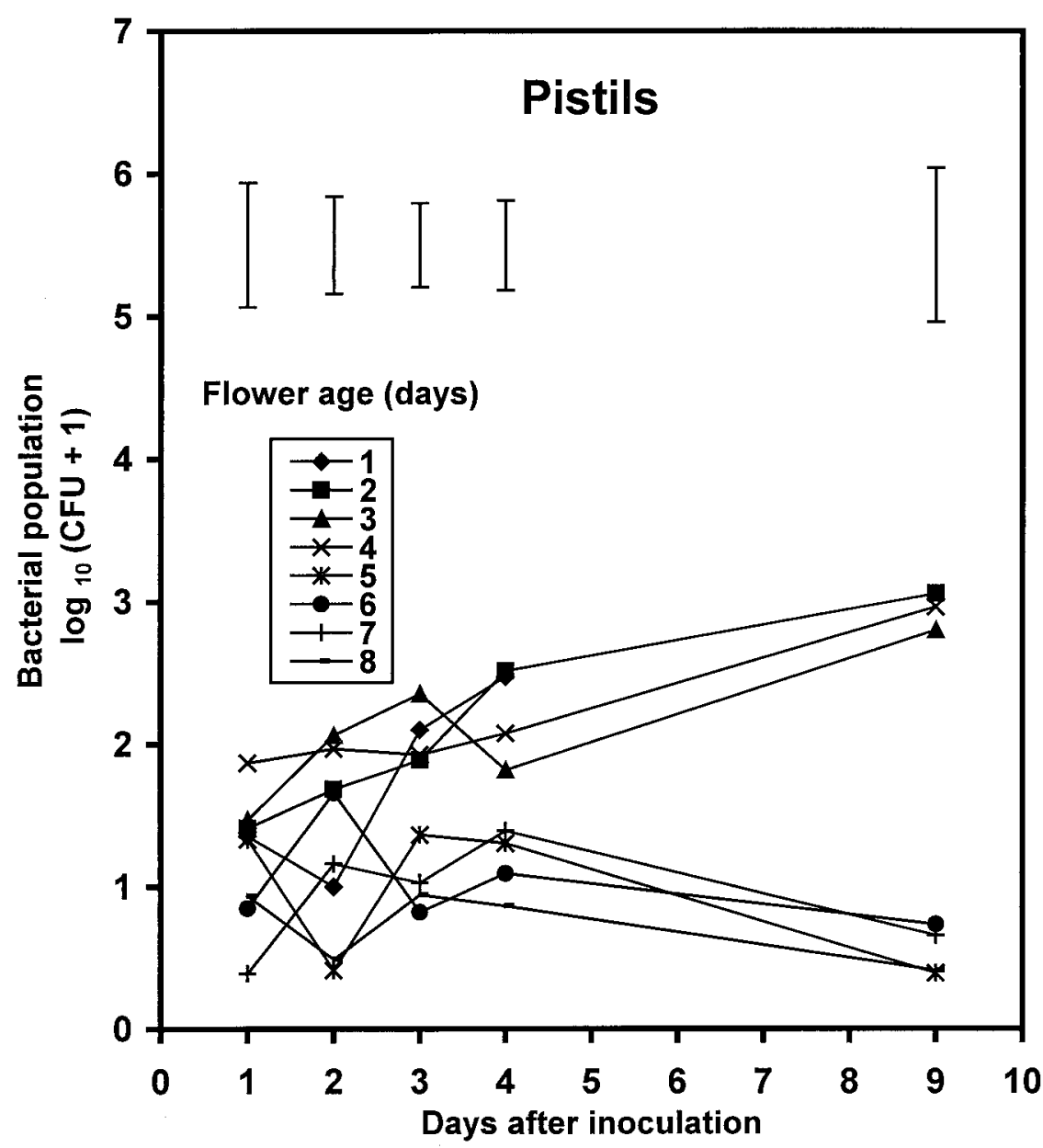

Fig. 3. Population dynamics of Pseudomonas fluorescens PfA506nr on pistils of cv. Royal Gala flowers inoculated when 1 to 8 days old at Blands Research Orchard, Hamilton, New Zealand. $P$. fluorescens was applied at a concentration of $3 \times 10^{7} \mathrm{CFU} / \mathrm{ml}$. Each point is the mean of counts from excised pistils from 15 flowers. Bars at top are LSD (0.05) values for each day.

Table 1. Weather data obtained from weather stations at research orchards following inoculation with Erwinia amylovora for sites in New Zealand and the United States ${ }^{y}$

\begin{tabular}{|c|c|c|c|c|c|c|c|c|c|c|c|c|}
\hline \multirow{3}{*}{$\begin{array}{l}\text { Flower } \\
\text { age }\end{array}$} & \multicolumn{6}{|c|}{ Blands Research Orchard, Hamilton, NZ } & \multicolumn{6}{|c|}{ Kaysville Research Orchard, UT } \\
\hline & \multirow[b]{2}{*}{ Date } & \multicolumn{3}{|c|}{ Temperature $\left({ }^{\circ} \mathrm{C}\right)$} & \multirow{2}{*}{$\begin{array}{l}\text { Rain } \\
(\mathbf{m m})\end{array}$} & \multirow[b]{2}{*}{ Risk $^{\mathbf{z}}$} & \multirow[b]{2}{*}{ Date } & \multicolumn{3}{|c|}{ Temperature $\left({ }^{\circ} \mathrm{C}\right)$} & \multirow{2}{*}{$\begin{array}{l}\text { Rain } \\
(\mathbf{m m})\end{array}$} & \multirow[b]{2}{*}{ Risk } \\
\hline & & Max. & Min. & Mean & & & & Max. & Min. & Mean & & \\
\hline 1 & Oct. 15 & 16.5 & 8.2 & 12.3 & 0.0 & M & May 8 & 23.3 & 4.2 & 13.7 & 0.0 & $\mathrm{H}$ \\
\hline 2 & 16 & 19.1 & 9.5 & 14.3 & 0.0 & M & 9 & 26.6 & 5.7 & 16.1 & 0.0 & $\mathrm{H}$ \\
\hline 3 & 17 & 19.0 & 3.6 & 11.3 & 0.0 & $\mathrm{~L}$ & 10 & 27.9 & 6.9 & 17.4 & 0.0 & $\mathrm{H}$ \\
\hline 4 & 18 & 18.1 & 5.9 & 12.0 & 0.0 & $\mathrm{~L}$ & 11 & 28.3 & 7.8 & 18.1 & 0.0 & $\mathrm{H}$ \\
\hline 5 & 19 & 19.0 & 8.0 & 13.5 & 0.0 & $\mathrm{~L}$ & 12 & 26.2 & 11.7 & 18.9 & 0.0 & $\mathrm{H}$ \\
\hline 6 & 20 & 181 & 6.0 & 12.9 & 0.0 & $\mathrm{~N}$ & 13 & 28.3 & 10.3 & 19.3 & 0.0 & $\mathrm{H}$ \\
\hline 7 & 21 & 19.0 & 7.6 & 13.3 & 0.0 & $\mathrm{~L}$ & 14 & 30.8 & 10.7 & 20.7 & 0.0 & $\mathrm{H}$ \\
\hline \multirow[t]{7}{*}{8} & 22 & 18.1 & 13.1 & 15.6 & 2.9 & $\mathrm{H}$ & 15 & 31.1 & 12.1 & 18.6 & 0.0 & $\mathrm{H}$ \\
\hline & & & & & & & 16 & 31.3 & 12.1 & 17.1 & 0.0 & $\mathrm{H}$ \\
\hline & & & & & & & 17 & 27.8 & 13.1 & 20.4 & 0.0 & $\mathrm{H}$ \\
\hline & & & & & & & 18 & 26.3 & 10.9 & 18.6 & 0.03 & I \\
\hline & & & & & & & 19 & 26.2 & 8.0 & 18.0 & 0.0 & $\mathrm{H}$ \\
\hline & & & & & & & 20 & 26.4 & 9.7 & 18.3 & 0.25 & I \\
\hline & & & & & & & 21 & 25.3 & 10.6 & 19.0 & 0.25 & I \\
\hline
\end{tabular}

\footnotetext{
y The population study was conducted 15 to 22 October 1996 in New Zealand and 8 to 15 May 1997 in the United States.

${ }^{\mathrm{z}}$ Blossom infection risks according to the MARYBLYT model are as follows: $\mathrm{L}=$ low, $\mathrm{M}=$ medium, $\mathrm{H}=$ high, and $\mathrm{I}=$ infection.
} 
ages are presented in Table 2. Higher bacterial mean populations were observed on older pistils, but similar levels were recovered on flowers ex pistil of all ages. Generally, high bacterial numbers ranging from $10^{4}$ to $10^{5} \mathrm{CFU} / \mathrm{ml}$ were recovered from even 1-day-old pistils and flowers. The range of bacteria recovered included $P$. agglomerans, fluorescent Pseudomonads, unidentified yellow and cream-colored bacteria.

Studies in USA. Significant differences were detected in bacterial populations obtained from pistils of different ages $(P=$ 0.01). Stigmas of 1- to 3-day-old flowers supported growth of E. amylovora, but the stigmas were not conducive to growth when flowers were inoculated when older than 3 days (Fig. 5). On pistils from 1- to 3-day-old flowers, E. amylovora multiplied exponentially and reached $10^{5}$ to $10^{7} \mathrm{CFU}$ per sample in 4 days from an initial population of $10 \mathrm{CFU}$ per sample. On pistils from flowers 4 to 6 days old, the bacterial populations did not increase but fluctuated between zero and the initial concentration of $10 \mathrm{CFU}$ per sample. E. amylovora did not multiply when inoculated on the 1- to 3-day-old flowers ex pistils, and the populations were characteristically lower than pistil populations (Fig. 6). In contrast to the NZ study, there were no clear differences in the bacterial numbers on flowers ex pistils of various ages. No rain was recorded during the course of population monitoring at the Kaysville site (Table 1).

Fire blight incidence. In the NZ study, a significantly higher $(P=0.01)$ percentage of 1- to 3-day-old flowers were infected compared with 5- to 8-day-old flowers (Table 3). Fire blight incidence was less than $17 \%$ for 5- to 8-day-old flowers, whereas the incidence was over $90 \%$ in 1 to 3-day-old flowers. An intermediate number of infections was observed on flowers inoculated when 4 days old. In the

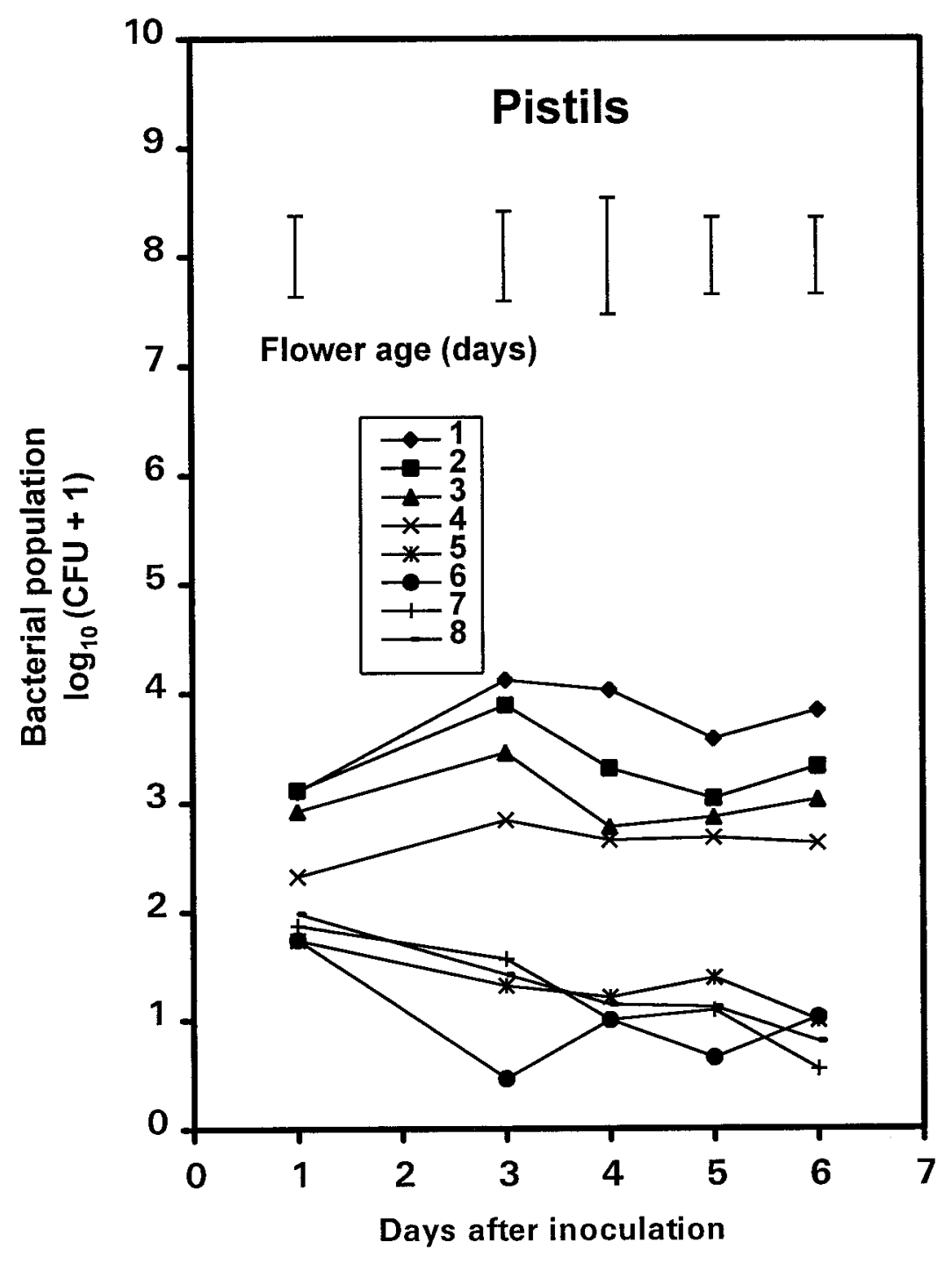

Fig. 4. Population dynamics of Pantoea agglomerans (Erwinia herbicola) Eh318nr on pistils of cv. Royal Gala flowers inoculated when 1 to 8 days old at Blands Research Orchard, Hamilton, New Zealand. P. agglomerans was applied at a concentration of $3 \times 10^{7} \mathrm{CFU} / \mathrm{ml}$. Each point is the mean of counts from excised pistils from 15 flowers. Bars at top are LSD (0.05) values for each day.
USA study, there was no clear pattern of infection of flower clusters compared with flower age.

Macroscopic observations. One-dayold flowers had newly opened petals that were cupped and deeper pink in color at the tip. The stigmas were light green, appeared fresh, and styles were short. Stamens were firm and cream-colored, not dehisced, and filaments were short and close together. On 2- and 3-day-old flowers, petals were fully opened and styles and filaments were longer. Stigmas still appeared light green and a few stamens had dehisced. Four-day-old flowers were not visually very different from 2- and 3-dayold flowers, except some stigmas appeared discolored upon close examination. Fiveday-old flowers started to show visible signs of aging. Stigmas were yellowish, and petals fell off when touched or had fallen off. On 6-day-old flowers, stigmas were shriveled and appeared dry and brown, and petals were absent. These descriptions generally agreed between the NZ and the USA sites. It has been observed in previous years that the appearance of 1- to 3-day-old flowers did not conform to the above descriptions if rain had occurred, because of damage by water (4). Some anthers had dehisced prematurely, and pollen stain was visible on the petals, giving the appearance of 4-day-old or older flowers.

SEM examination. SEM examination of flowers of different ages from both NZ and the USA revealed similar morphological changes corresponding with aging of stigmas. Scanning electron micrographs of stigmas are presented in Figure 7. Stigmas of 1-day-old flowers had distinctly rounded and plump papillae. Two- and 3-day-old stigmas had some collapsed papillae and apparently some stigmatic secretions between and on top of the papillae. On 4-dayold flowers, the majority of the papillae

Table 2. Populations of naturally occurring saprophytic bacteria isolated from parts of apple (cv. Royal Gala) flowers from 1 to 5 days old in New Zealand

\begin{tabular}{llc}
\hline \multirow{2}{*}{$\begin{array}{l}\text { Flower age } \\
\text { (days) }\end{array}$} & \multicolumn{2}{c}{ Population $\left(\log _{\mathbf{1 0}} \mathbf{C F U} / \mathrm{ml}\right)^{\mathrm{x}}$} \\
\cline { 2 - 3 } & Pistil & $\begin{array}{c}\text { Flower } \\
\text { ex pistil }\end{array}$ \\
\hline 1 & $3.43 \mathrm{a}^{\mathrm{y}}$ & 4.73 \\
2 & $3.51 \mathrm{a}$ & 4.71 \\
3 & $5.69 \mathrm{~b}$ & 4.66 \\
4 & $6.32 \mathrm{c}$ & 5.32 \\
5 & $5.93 \mathrm{~b}$ & 4.88 \\
& & $\mathrm{NS}^{\mathrm{z}}$ \\
\hline
\end{tabular}

${ }^{x}$ Populations were determined by washing the pistils and flowers ex pistils in 5 and $10 \mathrm{ml}$ respectively of phosphate buffered saline and $0.1 \mathrm{ml}$ of the wash spread on King's medium B (7). Colony counts were means of nine pistils or flowers ex pistils.

y Numbers within a column followed by a letter in common are not significantly different (Fisher's least significant difference, $P=0.1$ ).

${ }^{\mathrm{z}}$ Not significantly different. 
were markedly collapsed and the stigmatic surface was covered in mucilage. The mucilage formed a layer over the papillae on older stigmas and nearly covered the entire papillae on old stigmas. Stigmas of 4- to 6day-old flowers had progressively lost integrity and appeared shriveled. Increasing amounts of pollen grains were observed on older stigmas.

The scanning electron micrographs of the hypanthium from samples inoculated in November 1995 are presented in Figure 8. No bacteria were observed in the hypanthium of 1- or 2-day-old flowers, even on inoculated flowers. A few rod-shaped bacteria were found scattered around most hypanthia of 2-day-old flowers. With 3day-old flowers, bacteria were located in clumps, while some parts of the hypanthium had no bacteria. With 4- to 5-day-old flowers, bacteria were scattered over the surface of the hypanthium with high numbers at the base of anthers. There was no consistent trend between the presence of bacteria and whether the flowers had been inoculated. There was no obvious clumping of bacteria around the nectarthodes. However, the bacterial cell is sufficiently small for it to enter the nectarthodes.

Weather conditions. Weather conditions at the New Zealand site resulted in low to medium risk predictions according to MARYBLYT for blossom blight throughout the period from population monitoring to disease assessment (Table 1). The USA site experienced warmer temperatures and "high" or "infection" risks every day of the study period. While no rain occurred during the course of population monitoring, rain occurred 3 days after the sampling ceased that resulted in prediction of infection events according to the MARYBLYT model.

\section{DISCUSSION}

The clearly better growth of E. amylovora on 1- to 4-day-old flowers in NZ and 1- to 3-day-old flowers in the USA was a distinct contrast compared with flowers older than 4 days. The results obtained in both humid and arid environments provided supporting evidence that flower age influences the growth of E. amylovora. Since E. amylovora multiplies primarily on the stigmas, physiological or morphological changes in the stigmas should have a major influence on the growth of bacteria. This suggests that either certain factors related to the aging of stigmas inhibited the growth of this pathogen or a depletion of growth components became limiting to the growth of E. amylovora. The description of papillae of 1-day-old flowers agreed with that reported by Stant (14), but there was no description or illustration of the progressive degeneration of papillae in aging apple stigmas. Flowers that were 3 days old were not visually very different from 4- day-old flowers. However, rapid and significant changes in stigma morphology of young flowers as observed with SEM when compared with stigmas on flowers older than 4 days correspond with the marked difference in the ability of E. amylovora to grow on these sites. The inability of E. amylovora to multiply on stigmas older than 4 days appeared to be associated with collapse of the majority of papillae, which was clearly observed by SEM. The collapsed stigmatic surface and associated

Table 3. Mean numbers of apple flowers or clusters of various ages affected by fire blight 2 to 3 weeks after inoculation with Erwinia amylovora at $3 \times 10^{7}$ or $5 \times 10^{8} \mathrm{CFU} / \mathrm{ml}$ in New Zealand and U.S. studies, respectively

\begin{tabular}{lll}
\hline $\begin{array}{l}\text { Flower } \\
\text { age (days) }\end{array}$ & $\begin{array}{l}\text { NZ infected } \\
\text { flowers (\%) }\end{array}$ & $\begin{array}{c}\text { U.S. infected } \\
\text { clusters (\%) }\end{array}$ \\
\hline 1 & $91.1(3.5) \mathrm{a}^{\mathrm{Z}}$ & $26.3(5.3) \mathrm{ab}$ \\
2 & $93.1(3.8) \mathrm{a}$ & $17.7(4.3) \mathrm{a}$ \\
3 & $95.3(2.6) \mathrm{a}$ & $20.1(4.2) \mathrm{a}$ \\
4 & $53.5(9.7) \mathrm{b}$ & $37.9(4.4) \mathrm{bc}$ \\
5 & $10.1(9.8) \mathrm{c}$ & $47.2(4.6) \mathrm{c}$ \\
6 & $17.4(15.8) \mathrm{c}$ & $30.4(4.2) \mathrm{abc}$ \\
7 & $0.0(0)$ & - \\
8 & $0.0(0)$ & - \\
\hline
\end{tabular}

${ }^{\mathrm{z}}$ Numbers within a column followed by a letter in common are not significantly different (least significant difference, $P=0.1$ ). Standard errors of the means are shown in parentheses. Days 7 and 8 were not included in the analysis because all values were zero.

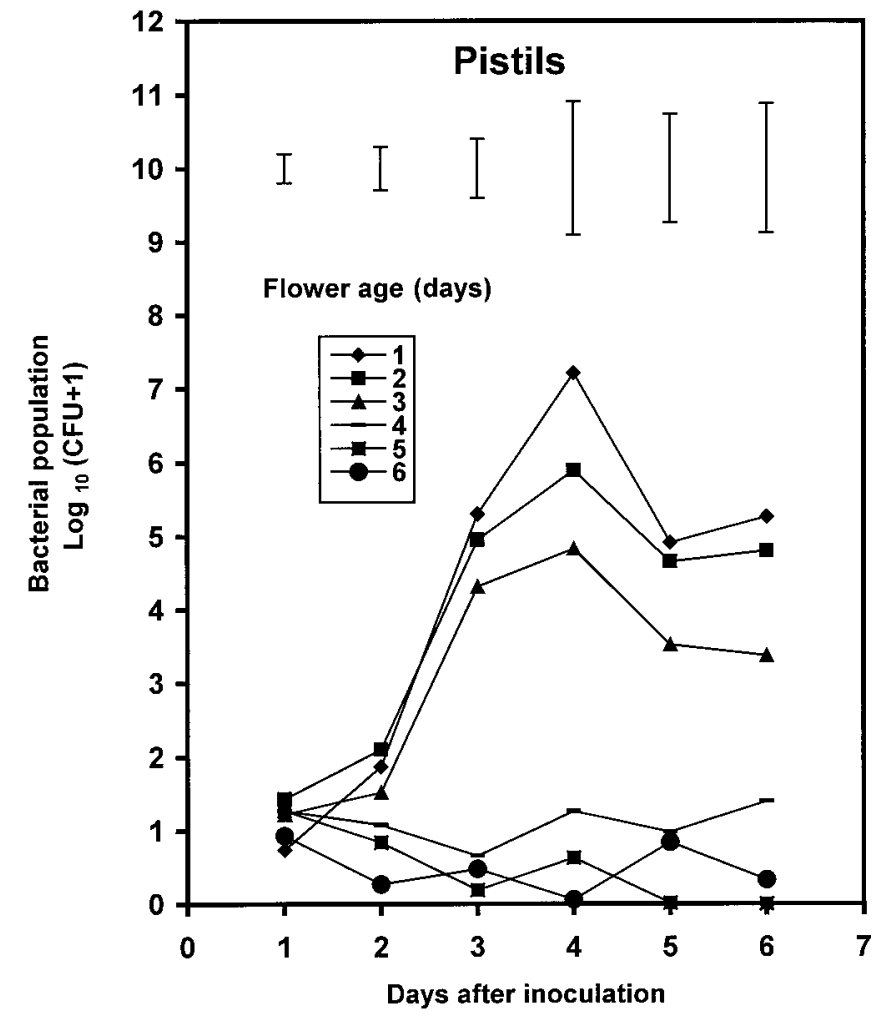

Fig. 5. Population dynamics of Erwinia amylovora on pistils of cv. Royal Gala flowers inoculated when 1 to 6 days old at Kaysville Research Orchard, UT. E. amylovora was applied at a concentration of $5 \times 10^{8} \mathrm{CFU} / \mathrm{ml}$. Each point is the mean of counts from excised pistils from 15 flowers. Bars at top are LSD (0.05) values for each day after inoculation.

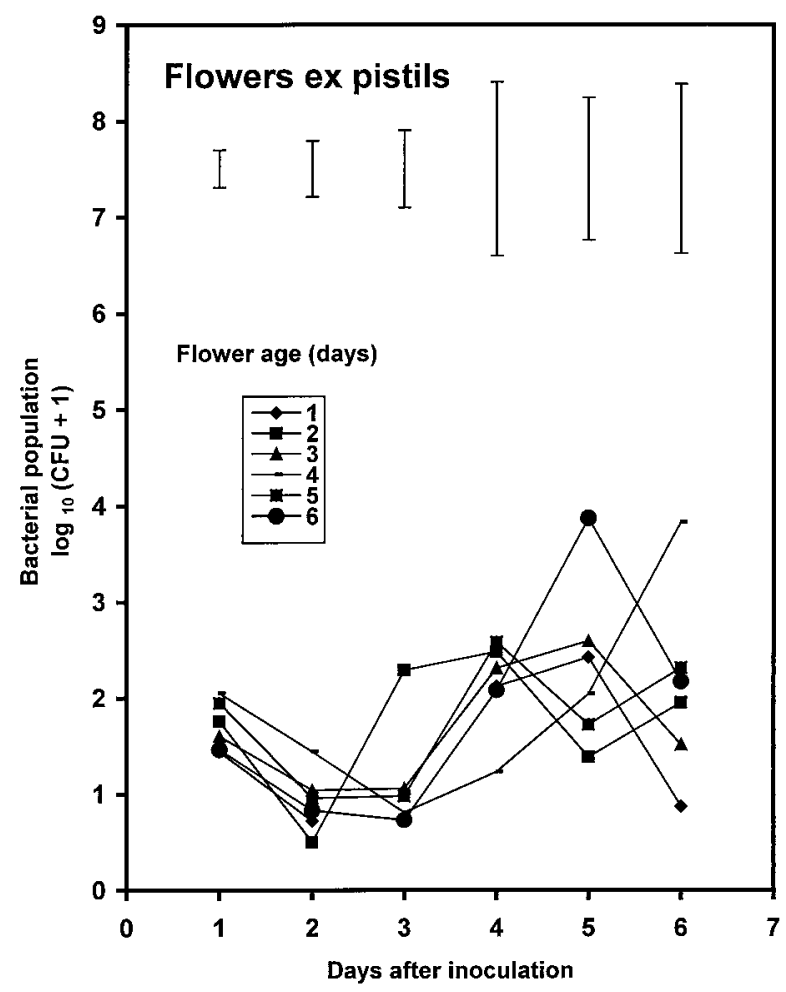

Fig. 6. Population dynamics of Erwinia amylovora on flowers ex pistils of cv. Royal Gala inoculated when 1 to 6 days old at Kaysville Research Orchard, UT. E. amylovora was applied at a concentration of $5 \times 10^{8}$ $\mathrm{CFU} / \mathrm{ml}$. Each point is the mean of counts from 15 flowers ex pistils. Bars at top are LSD (0.05) values for each day after inoculation. 
stigmatic secretions apparently constitute unfavorable colonization sites for the bacteria. It is likely that significant changes in the amount of mucilage produced and the morphology of the papilla surface lead to changes in the physical and chemical nature of the surface. Stigmas of 5- to 6-day old flowers were visually dry, a condition also less conducive to bacterial colonization.

Heslop-Harrison et al. $(5,6)$ grouped stigmas of plants in the Rosaceae family under the "wet" stigma group. The stigmas of this group produce free fluid that coats the tip of the papilla. On hawthorn (Crataegus monogyna Jacq.), the stigmatic secretions were considered to provide nutrients and moisture that make the intercellular spaces between the papillae a favorable environment for bacterial multiplication (22). E. amylovora was reported to exhibit an epiphytic growth phase in the intercellular spaces between the papillae of hawthorn stigmas and an invasive phase where the bacteria infected the secretory tissue below the papillae (22). In other plant species, the stigmatic exudate is rich in proteins, free amino acids, and carbohydrates (1). In Malus and other plant species, the stigma provides a moist, nutritious environment for pathogen growth $(10,21)$, yet infection of the pistils by E. amylovora is rare $(12,16)$. It is not known if the mucilage that covered the stigmatic surface of Malus spp. is inhibitory to the bacteria or at some stage acts as a barrier that prevents bacteria from becoming established on and between the papillae. Uwate and Lin (19) suggested that the presence of phenolic compounds in the mucilage of stigmas of sweet cherry (Prunus avium) might have a role in disease resistance. It has also been reported that phenolic compounds occurred in stigmatic exudates of other plant species $(5,6,8,10,11)$. It is commonly known that as plant tissues senesce, a complex chain of physiological and biochemical events is triggered. The secondary course of events may involve generation of metabolites that may have a role in plant defense.

It was reported in the USA that healthy, newly opened apple and pear flowers were relatively free of bacteria (16), and as the flower aged, pathogenic and saprophytic bacteria multiplied to high populations. In contrast, in the NZ study, populations of natural saprophytic bacteria of approximately $10^{4} \mathrm{CFU}$ per flower were generally found on stigmas and flowers ex pistils of all ages. Similar saprophytic bacterial numbers were present on stigmas of 3- to 6-day-old flowers even though the numbers of E. amylovora recovered from these flowers differed. Since high populations of saprophytic bacteria were present on both 3- and 4-day-old and older (5- to 6-dayold) stigmas, it was clear that saprophytic bacteria were not responsible for inhibiting the growth of E. amylovora on flowers older than 4 days. It is interesting that upon inoculation, both PfA506nr and Eh318nr, which are saprophytic in nature, behaved similarly to the pathogen and were unable to multiply exponentially when inoculated on pistils older than 4 days. The timing of applications of biological control agents is therefore important to ensure successful colonization and growth.

Both the NZ and USA studies confirmed previous reports $(12,16)$ that $E$. amylovora grows much better on pistils when compared with other flower parts. This demonstrates the importance of stigmas as a site where colonization takes place and high populations develop. The NZ study also supported the role of rain in dispersal of $E$. amylovora as reported earlier $(16,17)$. On the day rain was recorded, the increase in populations of E. amylovora on 1- to 4-day old flowers ex pistils corresponded with a
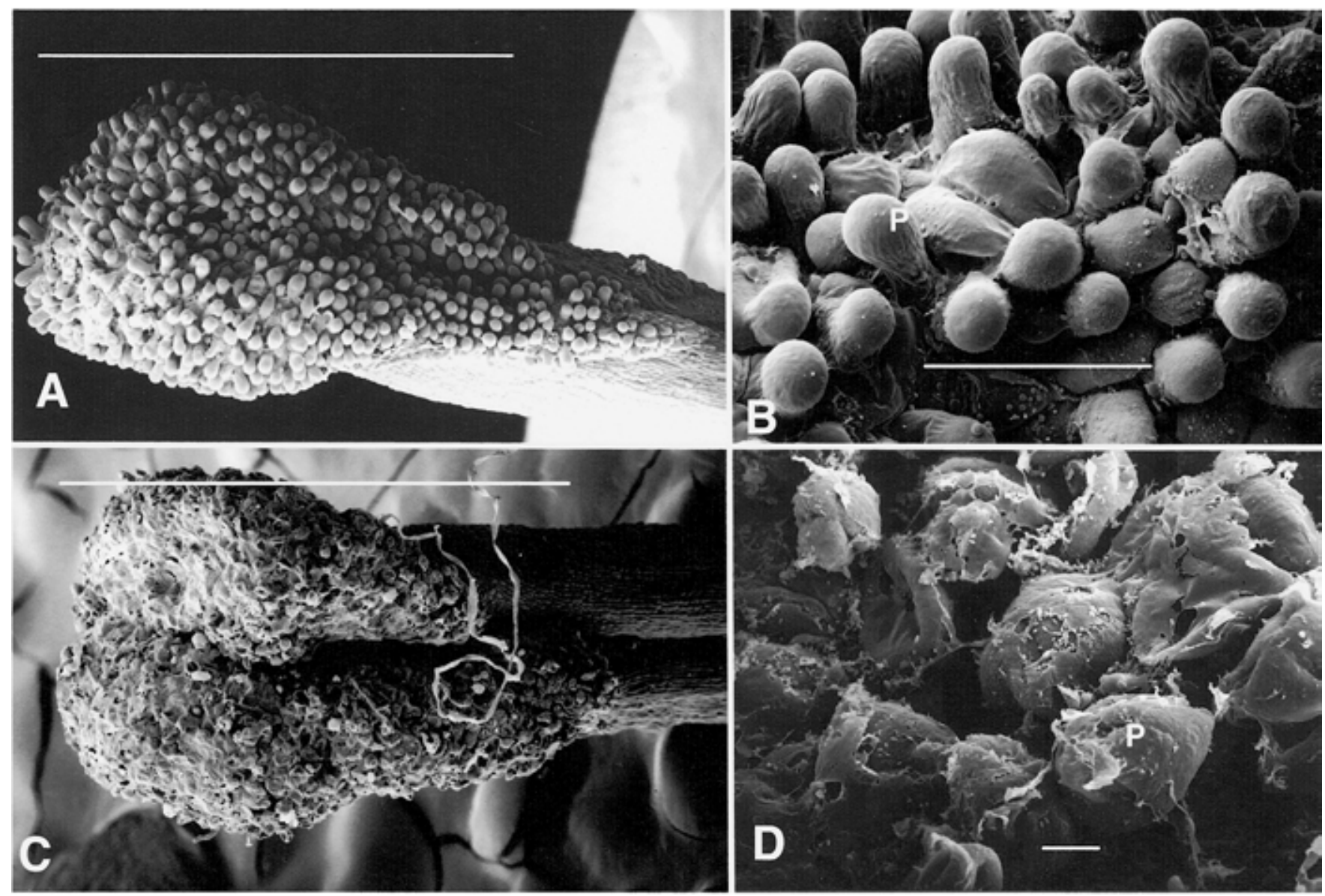

Fig. 7. Scanning electron micrographs of apple cv. Royal Gala stigmas of various ages. A, Stigma of a newly opened flower showing round and turgid club-shaped papillae (bar $=1 \mathrm{~mm}$ ). B, Close-up of papillae showing rounded and turgid cells $(\mathrm{bar}=0.1 \mathrm{~mm})$. C, Stigma of a 4-day-old flower with collapsed papillae and a stigmatic surface that has lost integrity $(\mathrm{bar}=1 \mathrm{~mm})$. D, Papillae of a 4-day-old stigma that are collapsed and covered in mucilage with cells of Erwinia amylovora embedded (bar $=10 \mu \mathrm{m}$ ). 
drop in populations on pistils of the same age. The dispersal of bacterial populations from the stigmas to the hypanthium results in blossom infections.

The higher level of infection on young flowers corresponded with higher bacterial populations on the pistils and flowers ex pistils in the NZ study. The blossom blight incidence at the Kaysville site was complicated by highly favorable conditions for fire blight during the course of the study and occurrence of three infection events prior to disease assessment. The assessment of whole flower clusters at the USA site might not have provided an accurate reflection of disease incidence compared with the NZ site. Dispersal of epiphytic $E$. amylovora to newly opened flowers in the flower clusters probably resulted in infections and confounded the assessment of the various aged flowers that were inoculated.

The preferential pattern of growth of $E$. amylovora on young pistils was consistent between the two sites despite very different environmental conditions. The higher temperatures at the USA orchard stimulated more rapid growth of E. amylovora when compared with the temperatures and growth rates at the NZ orchard. This study confirms the effect of temperatures and resulting heat accumulation on the growth of the bacteria. Temperature is the main environmental factor used in predictive models for fire blight $(13,15,18)$. Higher temperatures also accelerate the maturation of flowers (21). Therefore, the more arid conditions and warmer temperatures at the USA site when compared to the NZ site accelerated the aging of stigmas, which shortened the number of days (from 4 to 3 days) that flowers were conducive to growth of E. amylovora.

The influence of stigma aging on the ability of flowers to support epiphytic growth of E. amylovora is important for understanding the epidemiology of fire blight. The findings indicate that establishment and growth of E. amylovora on the stigmas occurs primarily within a 3- to 4-day period after opening. Consequently, each flower may have a short period of only 3 to 4 days when conditions are conducive to epiphytic growth of E. amylovora. If the inoculum is unable to reach the stigmas either by rain splash, insect transmission, or other means during this period, the opportunity for growth may be relatively low. Some apple cultivars are prone to an extended bloom period resulting in flowers of different ages occurring at the same time on the tree. This characteristic is particularly conducive for fire blight infections since it lengthens the risk period and provides a longer time for epiphytic growth and spread on 1- to 4-day-old flowers as they sequentially develop. This also occurs during years when weather conditions favor a long bloom with numerous secondary flowers (3). This knowledge is also important in optimizing the use of biological control bacteria, since their growth is also affected by flower age. Bio-
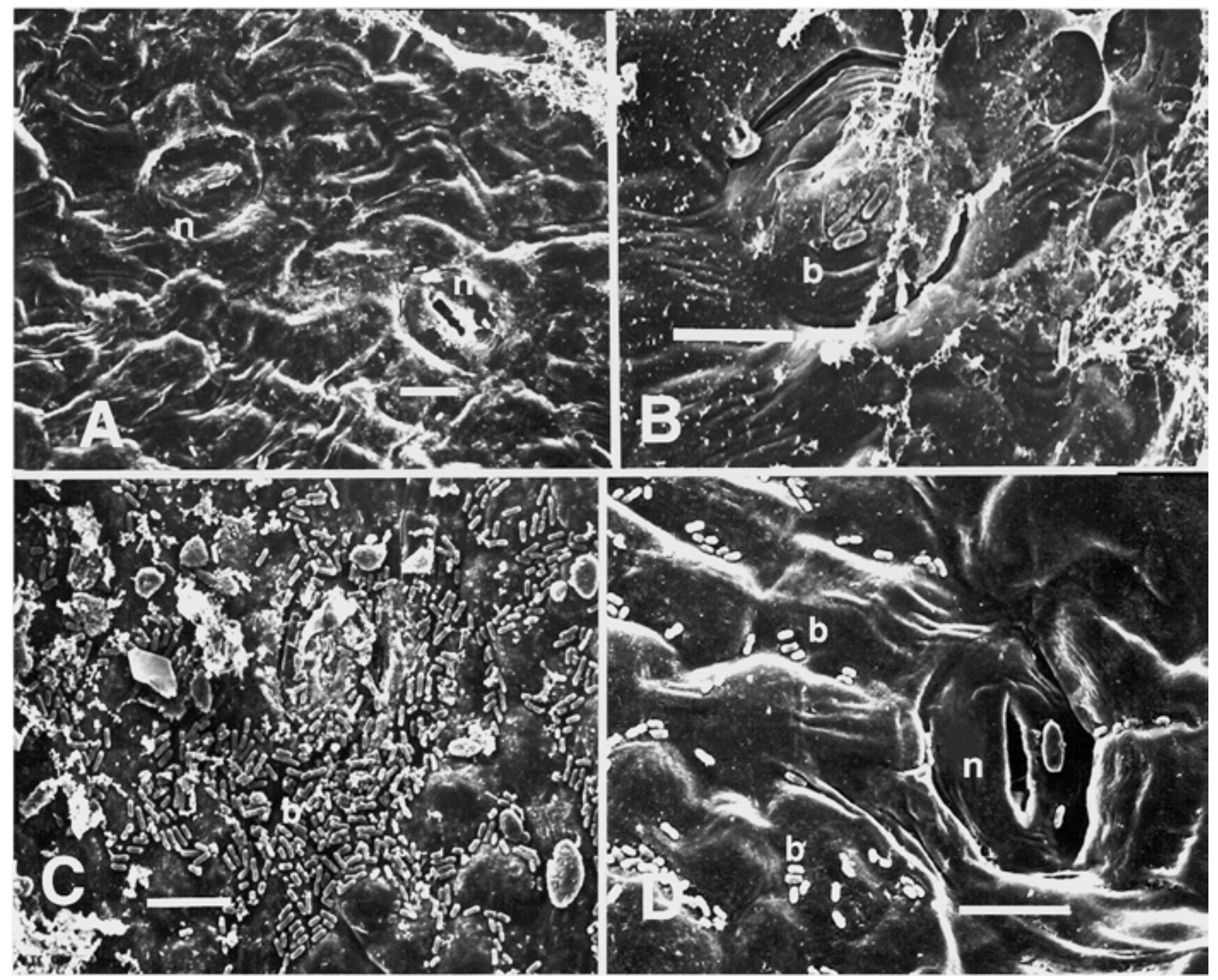

Fig. 8. Scanning electron micrographs of hypanthium of apple cv. Royal Gala flowers of various ages. A, Hypanthium with two nectarthodes (n) on a 2day-old flower. B, A few bacteria (b) were found on the hypanthium of 2-day-old flowers inoculated with Erwinia amylovora. C, Hypanthium of a 3-dayold flower inoculated with E. amylovora with numerous bacteria (b) evident. D, Nectarthode (n) on the hypanthium of a noninoculated 3-day-old flower with a few aggregations of bacteria. Bar $=10 \mu \mathrm{m}$. 
control bacteria need to be applied at the appropriate time so that they can colonize young flowers under optimal conditions.

\section{ACKNOWLEDGMENTS}

We thank the New Zealand Ministry of Research, Science and Technology for funding of the Foundation for Research Science and Technology Programme, CO6614, and the NZ/USA Collaborative Science Programme Award, and Utah State Horticulture Association for funding support. We also thank I. Hallet for SEM imaging, B. Dow for statistical analysis, R. Bedford, S. O. Hutchings, C. Thomson, D. Wilson, T. Eden, and S. Ockey for technical assistance. We acknowledge the support of the Utah Agriculture Experiment Station, paper no. 7534 .

\section{LITERATURE CITED}

1. Atkinson, A. H., Lind, J. L., Clarke, A. E., and Anderson, M. A. 1993. Molecular and structural features of the pistil of Nicotiana alata. Pages 15-26 in: Molecular Botany: Signals and the Environment. D. J. Bowles, P. M. Gilmartin, J. P Knox, and G. G. Lunt, eds. Biochemical Society Symposium No. 60. Portland Press, London.

2. Gouk, S. C., Bedford, R. J., and Hutchings, S. O. 1996. Effect of apple flower phenology on growth of Erwinia amylovora. Phytopathology $86: \mathrm{S} 42$.

3. Gouk, S. C., Bedford, R. J., Hutchings, S. O., Cole, L., Voyle, M. D., and Hoyte, S. M. 1996. Evaluation of the MARYBLYT ${ }^{\mathrm{TM}}$ model for predicting fire blight blossom in- fections in New Zealand. Acta Hortic. 411:109-116.

4. Gouk, S. C., and Thomson, S. V. 1999. Influence of age of apple flowers on growth of Erwinia amylovora. Acta Hortic. 489:525528.

5. Heslop-Harrison, J. 1976. A new look at pollination. Rep. E. Malling Res. Stn. 1975:141-157.

6. Heslop-Harrison, J., Heslop-Harrison, Y., and Barber, J. 1975. The stigma surface in incompatibility response. Proc. R. Soc. Lond. B. 188:287-297.

7. King, E. O., Ward, M. K., and Raney, D. E. 1954. Two simple media for the demonstration of pyocyanin and fluorescin. J. Lab. Clin. Med. 44:301-307.

8. Knox, R. B. 1984. Pollen-pistil interactions. Pages 508-608 in: Cellular Interactions. Encyclopedia of Plant Physiology. H. F. Linskens and J. Heslop-Harrison, eds. SpringerVerlag, Berlin.

9. Laurenson, M. R., and Beresford, R. M. 1996. Decision support software as a medium for technology transfer in plant protection. Proc. N.Z. Plant Prot. Conf. 49:85-89.

10. Martin, F. W. 1969. Exudates of the stigmas of ten species. Am. J. Bot. 56:1023

11. Martin, F. W. 1970. The ultraviolet absorption profile of stigmatic extracts. New Phytol. 69:425-430.

12. Pusey, P. L. 1997. Crab apple blossoms as a model for research on biological control of fire blight. Phytopathology 87:1096-1102.

13. Smith, T. J. 1999. Report on the development and use of Cougarblight 98C - A situationspecific fire blight risk assessment model of apple and pear. Acta Hortic. 489:429-443.

14. Stant, M. Y. 1981. Stigma investigations in Malus. Micron 12:170-180.

15. Steiner, P. 1990. Predicting apple blossom infections by Erwinia amylovora using the MARYBLYT model. Acta Hortic. 273:139148.

16. Thomson, S. V. 1986. The role of the stigma in fire blight infections. Phytopathology 76:476-482.

17. Thomson, S. V., and Gouk, S. C. 1992. The effect of rain on the development of Erwinia amylovora and E. herbicola populations on apple flowers. Proc. N.Z. Plant Prot. Soc. Conf. 45:301-303.

18. Thomson, S. V., Schroth, M. N., Moller, W. J. and Reil, W. O. 1982. A forecasting model for fire blight of pear. Plant Dis. 66:576-579.

19. Uwate, W. J., and Lin, J. 1981. Development of the stigmatic surface of Prunus avium L. sweet cherry. Am. J. Bot. 68:1165-1176.

20. Van der Zwet, T., and Keil, H. L. 1979. Fire blight - A bacterial disease of rosaceous plants. U.S. Dep. Agric. Handb. 510.

21. Williams, R. R., Brain, P., Church, R. M., and Flook, V. A. 1984. Flower receptivity, pollen transfer and fruit set variations during a single flowering period of Cox's Orange Pippin apple. J. Hortic. Sci. 59:337-347.

22. Wilson, M., Epton, H. A. S., and Sigee, D. C. 1989. Erwinia amylovora infection of hawthorn blossom. II. The stigma. J. Phytopathol. 127:15-28. 